\title{
Crystallographic and Computational Analysis of 4H-Pyran-3-Carboxylate Derivative Tethered with Amino and Methacryloyloxyethy 1 Units
}

\author{
Udhaya Kumar, Shunmugam Iniyaval, Kannan Gokula Krishnan, Muthiah Pillai Velayutham \\ Pillai, Chennan Ramalingan
}

\begin{abstract}
A single crystal of pyran derivative 1 was grown and analysed. The molecular structure of the same was theoretically executed through DFT approach. The frequencies and geometrical parameters obtained from computations are in good accord with the ones obtained through experimental. The calculated energies of HOMO and LUMO imply that transfer of charge happens within the molecule. Besides, the MEP analysis of the molecule 1 was examined using DFT calculations. X-Ray structural analysis (single crystal) of the molecule 1 implies that the pyran structural unit of the molecule adopts "flattened-boat" conformation.
\end{abstract}

Keywords: Crystal structure, Pyran derivative, DFT, HOMO-LUMO

\section{INTRODUCTION}

In recent years, great interests are shown towards the reactions under the category of multi-component, known as MCRs, in organic synthesis as well as medicinal chemistry domains.[1], [2] These methodologies provide a variety of advantages such as eco-friendliness, solvent-free strategies, atom economy, high selectivity, structural diversity, and good yields.[3]-[5] In particular, MCRs have been mostly applied in the synthesis of heterocyclic compounds.[6]-[8] Consequently, development of efficient and green reaction strategies focused on target molecules is a significant challenge in synthetic organic chemistry.[9], [10]

Revised Manuscript Received on December 17, 2019.

* Correspondence Author

Chandran Udhaya Kumar, Department of Chemistry, School of Advanced Sciences, Kalasalingam Academy of Research and Education (Deemed to be University), Krishnankoil, 626 126, Tamilnadu, India. Email: udhayaachem86@gmail.com

Shunmugam Iniyaval, Department of Chemistry, School of Advanced Sciences, Kalasalingam Academy of Research and Education (Deemed to be University), Krishnankoil, 626 126, Tamilnadu, India. Email: iniyaval.s@klu.ac.in

Kannan Gokula Krishnan, Department of Chemistry, School of Advanced Sciences, Kalasalingam Academy of Research and Education (Deemed to be University), Krishnankoil, 626 126, Tamilnadu, India. Email: gokulskrishnank83@gmail.com

Muthiah Pillai Velayutham Pillai, Department of Chemistry, School of Advanced Sciences, Kalasalingam Academy of Research and Education (Deemed to be University), Krishnankoil, 626 126, Tamilnadu, India. Email: m.velayuthampillai83@klu.ac.in

* Chennan Ramalingan, Department of Chemistry, School of Advanced Sciences, Kalasalingam Academy of Research and Education (Deemed to be University), Krishnankoil, 626 126, Tamilnadu, India. Email: ramalinganc@gmail.com
It is known that $4 H$-pyran and pyran-annulated ones are privileged heterocyclic structural cores because of the fact that many of their derivatives possess useful pharmacological properties[11], [12] and a wide range of biological profiles, which include antimalarial, anticancer, antimicrobial, anti-HIV, anti-inflammatory and cytotoxic etc. [13]-[18] Various methodologies have been developed for the construction of pyran ring systems. A few of novel methods include three component reaction utilizing a variety of catalysts such as piperidine,[19], [20] $S$-proline,[21] basic ionic liquid,[22] hydroxyapatite (HAP),[23] nano $\mathrm{ZnO}$ [24] and heteropolyacids.[25]

In this piece of research, we disclose a detailed investigation on crystallographic and computational studies of $4 \mathrm{H}$-pyran-3-carboxylate derivative tethered with amino and methacryloyloxy)ethyl units (1). Computational calculations were performed on novel 4H-pyran-3-carboxylate derivative 1 to explore its molecular structure and also to investigate the energy levels of HOMO and LUMO utilizing DFT. Computationally realized results of structural parameters (optimized) and vibrational assignments are evaluated with the ones resulted through experimental.

\section{EXPERIMENTAL}

\section{A. Materials and methodologies}

All starting materials / reagents / solvents were obtained from commercial suppliers and utilized as such with no additional purification. Melting point was recorded in open air capillary. XRD Data (single crystal) were acquired using a Bruker Kappa CCD diffractometer with Mo $\operatorname{K} \alpha(\lambda=0.71073$ $\AA$ ) at room temperature. The title molecule 1 was synthesized by MCR strategy involving equimolar mixture of 2-(methacryloyloxy)ethyl 3-oxobutanoate, 3-bromo benzaldehyde and malononitrile in the presence of $\mathrm{K}_{2} \mathrm{CO}_{3}$ in water.

\section{B. Structural studies (X-Ray) of novel}

2-(methacryloyloxy)ethyl6-amino-4-(3-bromophenyl)-5-c yano-2-methyl-4H-pyran-3-carboxylate 1

A crystal of $\mathbf{1}$ was grown utilizing slow-evaporation methodology utilizing chloroform:ethanol mixture as a solvent system. Bruker, 
2004 APEX 2 diffractometer with $\mathrm{MoK} \alpha$ radiation $(\mathrm{K} \alpha=$ $0.71073 \AA$ ) at $293 \mathrm{~K}$ was used to collect diffraction data. Direct methods and successive Fourier difference synthesis (SHELXS-97) were utilized to solve the structure [26] and full matrix least square procedure on $\mathrm{F}^{2}$ with anisotropic thermal parameters was used to refine the same. SHELXL-97 was used to refine all non-hydrogen atoms.[27] The molecule novel $4 H$-pyran derivative 1 crystallizes in the triclinic system $(P-1$ space group) and there are two discrete compounds in the unit cell. There are 263 parameters refined with the number of unique reflections 3820 which roofed the residuals to $\mathrm{R} 1=$ 0.0554. Mercury 3.5.1 and ORTEP-3 [28] softwares were used to arrange the material for publication. Crystallographic data of novel $4 \mathrm{H}$-pyran derivative 1 are deposited in the CCDC (1842446).

\section{Computational details}

Theoretical calculation by single molecule approach was performed with a B3LYP [6-311++G (d,p)] method (gas phase) for all atoms within the framework of the DFT using the Gaussian 09W program.[29] The frequencies of vibrations calculated were scaled by 0.9679 , a characteristic scaled factor for the calculated method.[30] The theoretical calculation yielded very closer prediction of the electronic and vibrational spectra as well as optimized geometry.

\section{RESULTS AND DISCUSSION}

\section{A. Target 4H-pyran-3-carboxylate derivative 1}

The target chemical entity $4 H$-pyran-3-carboxylate derivative 1 was synthesized by one-step three component reaction. A method of slow evaporation was adopted employing ethanol and chloroform as solvents to grow the single crystals.<smiles>C=C(C)C(=O)OCCOC(=O)C1=C(C)OC(N)=C(C#N)C1c1cccc(Br)c1</smiles>

Figure 1

\section{B. Structural and theoretical studies}

C. X-Ray structural (single crystal) and optimized geometrical analysis of $4 \mathrm{H}$-pyran derivative 1



Fig. 2. ORTEP View of 4H-pyran derivative 1
The 4H-pyran derivative 1 crystallized in the system of triclinic with P-1 space group and the cell parameters correspond to, $\mathrm{a}=8.2432(2) \AA, \mathrm{b}=11.7555(3) \AA, \mathrm{c}=$ 12.2738(3) $\AA, \alpha=63.6170(10)^{\circ}, \beta=72.8740(10)^{\circ}, \gamma=$ $71.711(2)^{\circ}$ and $Z=2$. The ORTEP view and packing diagram of the molecule 1 are shown in Fig. 2 and Fig. 3, respectively. Data of crystal and refinement features of structure of the molecule 1 are provided in Table I. The unity of crystal is realized through hydrogen bonds (intermolecular). The $\mathrm{N}-\mathrm{H} \cdots \mathrm{N} \equiv \mathrm{C}$ as well as $\mathrm{N}-\mathrm{H} \cdots \mathrm{O}=\mathrm{C}$ contacts possess bond distances of nearly 3.061 and $2.937 \AA$, respectively.

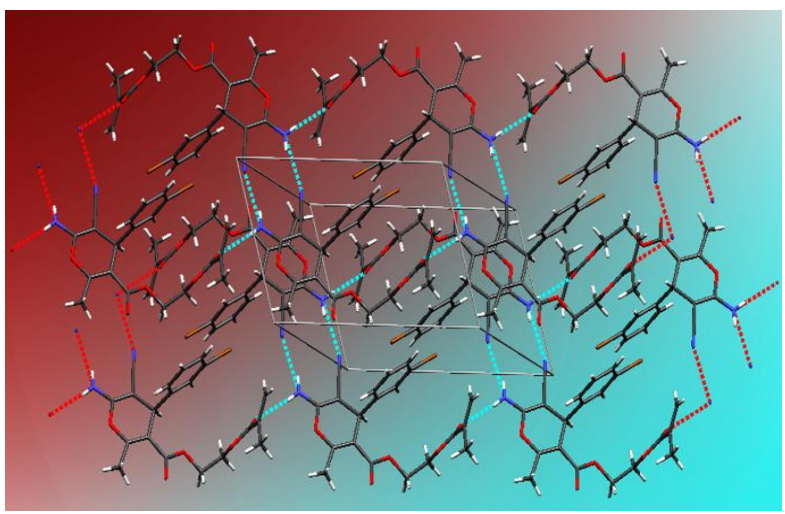

Fig. 3. Packing diagram of $4 \mathrm{H}$-pyran derivative 1

Table - I

Crystallographic and Refinement Data of $4 H$-pyran derivative 1

\begin{tabular}{ll}
\hline Empirical formula & $\mathrm{C}_{20} \mathrm{H}_{19} \mathrm{Br} \mathrm{N}_{2} \mathrm{O}_{5}$ \\
Formula weight & 447.28 \\
Temperature & $296(2) \mathrm{K}$ \\
Wavelength & $0.71073 \AA$ \\
Crystal system, space group & Triclinic, $\mathrm{P}-1$ \\
& $\mathrm{a}=8.2432(2) \AA$ \\
& $\alpha=63.6170(10)^{\circ}$ \\
& $\mathrm{b}=11.7555(3) \AA$ \\
Unit cell dimensions & $\beta=72.8740(10)^{\circ}$ \\
& $\mathrm{c}=12.2738(3) \AA$ \\
& $\gamma=71.711(2)^{\circ}$ \\
Volume & $994.72(4) \AA^{3}$ \\
Z, Calculated density & $2,1.493 \mathrm{Mg} / \mathrm{m}^{3}$ \\
Absorption coefficient & $2.100 \mathrm{~mm}^{-1}$ \\
F(000) & 456 \\
Crystal size & $0.250 \times 0.160 \times 0.120 \mathrm{~mm}$ \\
Theta range for & 1.884 to $25.834^{\circ}$ \\
collection & \\
& $-10<=\mathrm{h}<=9,-14<=\mathrm{k}<=14$, \\
Limiting indices & $-15<=1<=15$ \\
& $14559 / 3820$ \\
Reflections collected / unique & \\
Completeness to theta $=$ & $99.5 \%$ \\
25.242 & Full-matrix least-squares \\
Refinement method & on $\mathrm{F}^{2}$ \\
Data / restraints / parameters & $3820 / 0 / 263$ \\
Goodness-of-fit on $\mathrm{F}^{2}$ & 1.054 \\
Final R, $\mathrm{R}_{\mathrm{W}}$ (obs, data) & $0.0554,0.1027$ \\
\hline
\end{tabular}


International Journal of Engineering and Advanced Technology (IJEAT) ISSN: 2249 - 8958, Volume-9, Issue-1S4, December 2019

Table - IIa: Selected bond length $\left(\mathrm{A}^{\circ}\right)$, bond angles $\left(^{\circ}\right)$ and torsion angles $\left(^{\circ}\right)$ of $4 \mathrm{H}$-Pyran derivative 1

\begin{tabular}{|c|c|c|c|c|c|}
\hline Torsion angle & Comp. & Expt. & Torsion angle & Comp. & Expt. \\
\hline N36-C2-C3-C4 & -179.796 & $175.1(3)$ & C7-C6-C19-040 & 179.9866 & $167.5(2)$ \\
\hline N36-C2-C3-C8 & 0.1764 & $-3.5(4)$ & $\mathrm{C} 6-\mathrm{C} 7-\mathrm{O} 38-\mathrm{C} 2$ & 32.4805 & $4.9(3)$ \\
\hline O38-C2-C3-C4 & 0.3484 & $-4.3(4)$ & $\mathrm{C} 32-\mathrm{C} 7-\mathrm{O} 38-\mathrm{C} 2$ & -147.661 & $-174.8(2)$ \\
\hline O38-C2-C3-C8 & -179.679 & $177.1(2)$ & C4-C9-C10-C12 & -180 & 177.1(2) \\
\hline $\mathrm{C} 3-\mathrm{C} 2-\mathrm{O} 38-\mathrm{C} 7$ & -32.4817 & $-3.7(3)$ & C17-C9-C10-C12 & 0 & $-0.3(4)$ \\
\hline $\mathrm{N} 36-\mathrm{C} 2-\mathrm{O} 38-\mathrm{C} 7$ & 147.6631 & $176.8(2)$ & C4-C9-C17-C15 & 179.9999 & $-177.6(3)$ \\
\hline C2-C3-C4-C6 & 29.9816 & $9.7(3)$ & C10-C9-C17-C15 & 0.0002 & $-0.1(4)$ \\
\hline C2-C3-C4-C9 & -89.959 & $-114.5(3)$ & $\mathrm{C} 9-\mathrm{C} 10-\mathrm{C} 12-\mathrm{Br} 1$ & 180 & $-179.62(18)$ \\
\hline C8-C3-C4-C6 & -149.991 & $-171.7(2)$ & C9-C10-C12-C13 & -0.0002 & $0.2(4)$ \\
\hline C8-C3-C4-C9 & 90.0681 & $64.0(3)$ & $\mathrm{Br1}-\mathrm{C} 12-\mathrm{C} 13-\mathrm{C} 15$ & -180 & $-179.8(2)$ \\
\hline C3-C4-C6-C7 & -29.9828 & $-8.5(3)$ & C10-C12-C13-C15 & 0.0003 & $0.4(4)$ \\
\hline C3-C4-C6-C19 & 149.9911 & $169.7(2)$ & C12-C13-C15-C17 & -0.0001 & $-0.8(5)$ \\
\hline C9-C4-C6-C7 & 89.958 & $114.9(2)$ & C13-C15-C17-C9 & -0.0001 & $0.7(5)$ \\
\hline C9-C4-C6-C19 & -90.0681 & $-66.9(3)$ & C6-C19-040-C20 & -150 & $-172.5(2)$ \\
\hline C3-C4-C9-C10 & -90.3658 & $-106.0(2)$ & O39-C19-040-C20 & 29.9997 & $8.1(4)$ \\
\hline C3-C4-C9-C17 & 89.6345 & $71.4(3)$ & O40-C20-C23-O41 & 60.0001 & $83.4(3)$ \\
\hline C6-C4-C9-C10 & 150.3653 & $131.6(2)$ & C23-C20-040-C19 & 179.9995 & $-154.8(2)$ \\
\hline C6-C4-C9-C17 & -29.6344 & $-50.9(3)$ & C20-C23-041-C26 & -180 & $-170.9(2)$ \\
\hline $\mathrm{C} 4-\mathrm{C} 6-\mathrm{C} 7-\mathrm{C} 32$ & 179.7949 & $-178.4(2)$ & O41-C26-C27-C28 & -0.0001 & $39.5(4)$ \\
\hline $\mathrm{C} 4-\mathrm{C} 6-\mathrm{C} 7-\mathrm{O} 38$ & -0.3462 & $1.9(4)$ & O41-C26-C27-C43 & 179.9998 & $-141.9(3)$ \\
\hline C19-C6-C7-C32 & -0.179 & $3.5(4)$ & O42-C26-C27-C28 & 179.9996 & $-139.7(3)$ \\
\hline C19-C6-C7-038 & 179.6799 & $-176.2(2)$ & O42-C26-C27-C43 & -0.0005 & $38.9(4)$ \\
\hline C4-C6-C19-039 & -179.987 & $168.7(3)$ & $\mathrm{C} 27-\mathrm{C} 26-\mathrm{O} 41-\mathrm{C} 23$ & -150.001 & $5.0(4)$ \\
\hline C4-C6-C19-040 & 0.0128 & $-10.7(3)$ & O42-C26-O41-C23 & 29.9999 & $-174.3(2)$ \\
\hline C7-C6-C19-039 & -0.0134 & $-13.1(4)$ & & & \\
\hline Bond length & Comp. & Expt. & Bond length & Comp. & Expt. \\
\hline $\mathrm{Br} 1-\mathrm{C} 12$ & 1.91 & $1.910(3)$ & C10-C12 & 1.3568 & $1.385(4)$ \\
\hline $\mathrm{C} 2-\mathrm{C} 3$ & 1.3555 & $1.348(3)$ & $\mathrm{C} 12-\mathrm{C} 13$ & 1.3584 & $1.364(4)$ \\
\hline C2-N36 & 1.47 & $1.331(4)$ & C13-C15 & 1.3568 & $1.373(4)$ \\
\hline $\mathrm{C} 2-038$ & 1.4384 & $1.367(3)$ & $\mathrm{C} 15-\mathrm{C} 17$ & 1.3998 & $1.389(4)$ \\
\hline $\mathrm{C} 3-\mathrm{C} 4$ & 1.5318 & $1.509(3)$ & C19-039 & 1.2584 & $1.188(3)$ \\
\hline $\mathrm{C} 3-\mathrm{C} 8$ & 1.54 & $1.415(3)$ & C19-040 & 1.43 & $1.323(3)$ \\
\hline C4-C6 & 1.5318 & $1.521(3)$ & $\mathrm{C} 2 \mathrm{O}-\mathrm{C} 23$ & 1.54 & $1.493(4)$ \\
\hline C4-C9 & 1.54 & $1.531(3)$ & $\mathrm{C} 20-040$ & 1.43 & $1.440(3)$ \\
\hline $\mathrm{C} 6-\mathrm{C} 7$ & 1.3555 & $1.333(3)$ & $\mathrm{C} 23-041$ & 1.43 & $1.442(3)$ \\
\hline C6-C19 & 1.54 & $1.475(4)$ & $\mathrm{C} 26-\mathrm{C} 27$ & 1.54 & $1.478(4)$ \\
\hline C7-C32 & 1.54 & $1.496(3)$ & $\mathrm{C} 26-041$ & 1.43 & $1.335(3)$ \\
\hline C7-038 & 1.4384 & $1.380(3)$ & $\mathrm{C} 26-042$ & 1.2584 & $1.199(3)$ \\
\hline C8-N37 & 1.1466 & $1.141(3)$ & $\mathrm{C} 27-\mathrm{C} 28$ & 1.54 & $1.417(4)$ \\
\hline C9-C10 & 1.3998 & $1.390(3)$ & $\mathrm{C} 27-\mathrm{C} 43$ & 1.3552 & $1.380(4)$ \\
\hline $\mathrm{C} 9-\mathrm{C} 17$ & 1.352 & $1.371(4)$ & & & \\
\hline Bond angle & Comp. & Expt. & Bond angle & Comp. & Expt. \\
\hline C3-C2-N36 & 119.3316 & $128.0(2)$ & $\mathrm{Br} 1-\mathrm{C} 12-\mathrm{C} 10$ & 119.7821 & $122.1(2)$ \\
\hline C3-C2-038 & 121.3358 & $121.7(2)$ & $\mathrm{Br} 1-\mathrm{C} 12-\mathrm{C} 13$ & 119.782 & $119.13(19)$ \\
\hline N36-C2-O38 & 119.3325 & 110.3(2) & C10-C12-C13 & 120.4359 & $122.1(2)$ \\
\hline C2-C3-C4 & 119.8405 & $123.4(2)$ & C13-C15-C17 & 120.0059 & $120.2(3)$ \\
\hline C2-C3-C8 & 120.0806 & 117.4(2) & C6-C19-039 & 120.0001 & 126.7(2) \\
\hline C4-C3-C8 & 120.0789 & 119.2(2) & C6-C19-040 & 120 & $111.2(2)$ \\
\hline C3-C4-C6 & 108.6241 & $109.03(18$ & O39-C19-040 & 119.9999 & 122.1(3) \\
\hline C3-C4-C9 & 109.722 & $110.9(2)$ & C23-C20-040 & 109.4714 & $107.6(2)$ \\
\hline C6-C4-C9 & 109.7219 & $112.33(19$ & $\mathrm{C} 20-\mathrm{C} 23-041$ & 109.4712 & 107.2(2) \\
\hline $\mathrm{C} 4-\mathrm{C} 6-\mathrm{C} 7$ & 119.8405 & $122.8(2)$ & $\mathrm{C} 27-\mathrm{C} 26-041$ & 120 & $112.0(2)$ \\
\hline C4-C6-C19 & 120.0797 & 117.6(2) & $\mathrm{C} 27-\mathrm{C} 26-\mathrm{O} 42$ & 120.0001 & 125.7(2) \\
\hline C7-C6-C19 & 120.0797 & $119.6(2)$ & O41-C26-O42 & 119.9999 & $122.2(2)$ \\
\hline C6-C7-C32 & 119.332 & $129.4(2)$ & C26-C27-C28 & 120 & $118.2(3)$ \\
\hline C6-C7-038 & 121.3356 & $122.5(2)$ & $\mathrm{C} 26-\mathrm{C} 27-\mathrm{C} 43$ & 120 & $117.1(3)$ \\
\hline C32-C7-O38 & 119.3322 & 108.1(2) & C28-C27-C43 & 120 & $124.7(3)$ \\
\hline C4-C9-C10 & 120.221 & $120.0(2)$ & C2-038-C7 & 112.7655 & $119.62(18)$ \\
\hline C4-C9-C17 & 120.2207 & $120.8(2)$ & C19-040-C20 & 109.4714 & $118.2(2)$ \\
\hline $\mathrm{C} 10-\mathrm{C} 9-\mathrm{C} 17$ & 119.5582 & $119.1(2)$ & C23-041-C26 & 109.4711 & $116.6(2)$ \\
\hline $\mathrm{C}-\mathrm{C} 10-\mathrm{C} 12$ & 120.0058 & $119.0(3)$ & & & \\
\hline
\end{tabular}

The geometry of optimized molecule 1 was computed by DFT-B3LYP [6-311++G (d,p)] method. The molecular structure along with numbering of atoms of $\mathbf{1}$ is provided in Fig. 4 and the selected experimental and theoretical torsion angles, bond angles and bond lengths are depicted in Table II 


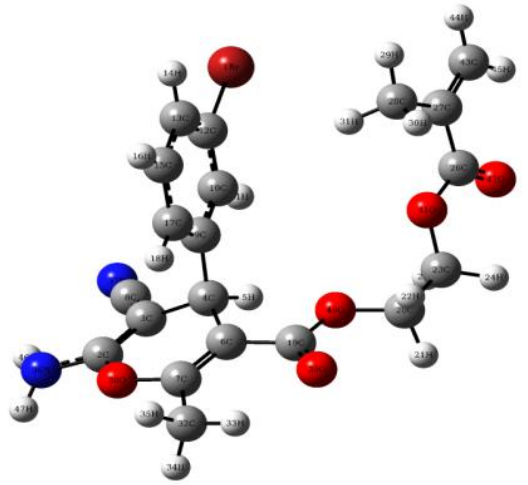

Fig. 4. Optimized Structure of 4H-pyran derivative 1

X-Ray structural (single crystal) and optimized geometrical analysis of the molecule $\mathbf{1}$ reflects the conformation of pyran ring scaffold is "flattened boat". This conformation is validated from the parameters of small puckering related with the atoms $\mathrm{O}(38)$ and $\mathrm{C}(4)$. The aforesaid atoms available at 1 and 4 positions of the pyran nucleus, which are displaced by (XRD/DFT) $0.044 / 0.127$ and $0.116 / 0.266 \AA$, respectively from the plane defined by $\mathrm{C}(2) / \mathrm{C}(3) / \mathrm{C}(6) / \mathrm{C}(7)$. The structural core of aryl is virtually vertical to the structural core of pyran with the angle of (XRD/DFT) $110.89 / 112.47^{\circ}$.

In the pyran scaffold, a couple of bonds such as $\mathrm{C}(6)-\mathrm{C}(7)$ and $\mathrm{C}(2)-\mathrm{C}(3)$ possess multiple bond (double bond) nature as shown in their bond distances [XRD/DFT; $\mathrm{C}(2)-\mathrm{C}(3)=1.348$ / 1.363 and $\mathrm{C}(6)-\mathrm{C}(7)=1.333 / 1.355 \AA$ ] . The parameters of bond related with the ester moiety (Table II) evidently indicate the density of partial $\pi$-electron delocalization over $\mathrm{COO}^{-}$unit and, the nitrile functionality is just about linear $\left[\mathrm{XRD} / \mathrm{DFT}\right.$; N(37)-C(8)-C(3)= $\left.179.4 / 179.2^{\circ}\right]$ and multiple bonded (triple bonded) in nature as well [XRD/DFT; $\mathrm{C}(8)-\mathrm{N}(37)=1.14 / 1.17 \AA]$. The incorporation of halogen decreases the density of electrons at the carbon atoms present in the phenyl ring. The $\mathrm{C}(12)-\mathrm{Br}(1)$ bond length is found to be (XRD/DFT) $1.91 / 1.910 \AA$.

In the side arm, bonds of $\mathrm{C}(19)-\mathrm{O}(39)$ and $\mathrm{C}(26)-\mathrm{O}(42)$ are in the double-bonded environment as shown by the distances between them [XRD/DFT; C(19)-O(39)= $1.188 / 1.242$ and $\mathrm{C}(26)-\mathrm{O}(42)=1.199 / 1.239 \AA]$. Besides, the bond $\mathrm{C}(27)-\mathrm{C}(28)$ is also double-bonded in character as shown by the distance between them [XRD/DFT; $\mathrm{C}(27)-\mathrm{C}(28)=1.417$ / $1.344 \AA]$. The optimized bond and torsion angles as well as bond lengths are in fine conformity with the structural parameters of X-ray of the title compound 1.

\section{IR spectral analysis of novel $4 \mathrm{H}$-pyran derivative 1}

The computational infrared spectra of $4 \mathrm{H}$-pyran derivative $\mathbf{1}$ is displayed in Fig. 5.

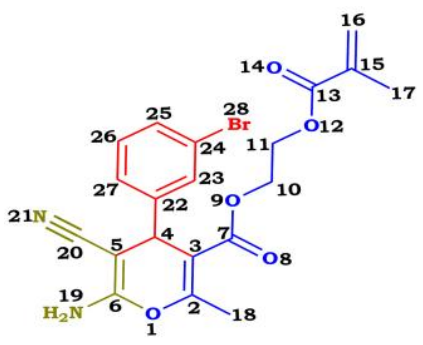

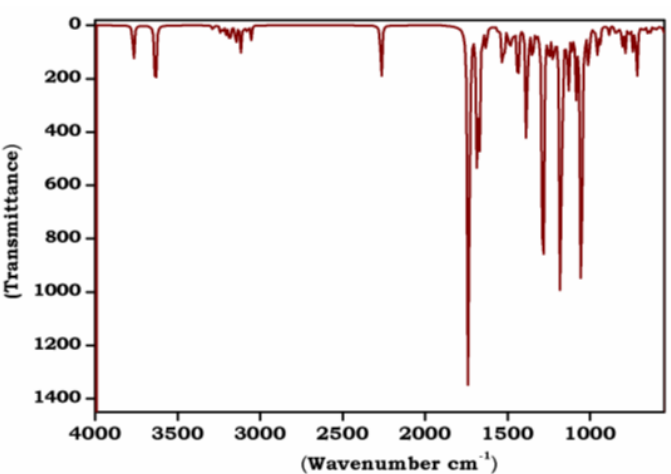

Fig. 5. Theoretical IR spectra of 1.

The stretching vibrations of $\mathrm{C}-\mathrm{H}$ in the aromatic ring usually appear nearly from 3100 to $3000 \mathrm{~cm}-1$ [31]. The vibrations (stretching) of $\mathrm{C}-\mathrm{H}$ in the aryl ring are theoretically obtained at 3203, 3190, 3187 and $3170 \mathrm{~cm}-1$. Further, the stretching vibrations of $\mathrm{C}-\mathrm{H}$ in the aliphatic region are theoretically observed at 3062, 3053, 3036 and $3032 \mathrm{~cm}-1$. The computed vibrational frequencies (unscaled and scaled) are presented in Table III.

In the FT-IR spectrum, the $\mathrm{C}=\mathrm{O}$ group with various environments generally appear as a strong band in the range between 1800-1600 $\mathrm{cm}^{-1}[31]$, [32]. In the 4H-pyran derivative 1 , the $\mathrm{C}=\mathrm{O}$ stretching vibrations of $\mathrm{O} 14=\mathrm{C} 13$, attached to carbon containing olefin and methyl group and $\mathrm{O} 8=\mathrm{C} 7$, connected to pyran molecule are theoretically resulted at 1777 and $1763 \mathrm{~cm}^{-1}$, respectively.

Besides, the nitrile groups normally provide unique spectral values and gives intense absorption between 2280 and $2200 \mathrm{~cm}^{-1}$. As a result of theoretical calculation at B3LYP level, the stretching vibration of nitrile functionality is observed at $2299 \mathrm{~cm}^{-1}$. Additionally, the existence of an amine (primary) functionality usually shows vibrations (stretching) of N-H in the range between 3400 and $3300 \mathrm{~cm}^{-1}$. The theoretical spectrum of FT-IR of $4 H$-pyran derivative 1 depicts two typical bands at 3686 and $3573 \mathrm{~cm}^{-1}$.

Further, in most of the bromoaryl molecules, the stretching vibrations of $\mathrm{C}-\mathrm{Br}$ present in the range between 650 and 395 $\mathrm{cm}^{-1}$ [32]. In the simulated spectrum of $4 H$-pyran derivative $\mathbf{1}$, the aromatic $\mathrm{C}-\mathrm{Br}$ stretching vibrations appeared at $679 \mathrm{~cm}^{-1}$.

Table- III: Selected simulated FT-IR spectral data of $4 H$-pyran derivative 1

\begin{tabular}{|c|c|c|c|c|}
\hline Mode & Unscaled & Scaled & Intensity & Assignment \\
\hline 1 & 446 & 431 & 53.4 & $\begin{array}{l}\text { гС17C15C13C12(29); } \\
\tau \mathrm{Br} 1 \mathrm{C} 10 \mathrm{C} 13 \mathrm{C} 12(18) ; \\
\text { гН16C15C17C9(14) }\end{array}$ \\
\hline 2 & 496 & 479 & 11.09 & $\begin{array}{l}\beta \mathrm{N} 36 \mathrm{C} 2 \mathrm{O} 38(11) ; \\
\beta \mathrm{N} 37 \mathrm{C} 8 \mathrm{C} 3(10) ; \\
\Gamma \mathrm{N} 37 \mathrm{C} 8 \mathrm{C} 3 \mathrm{C} 4(10)\end{array}$ \\
\hline 3 & 514 & 497 & 2.64 & $\begin{array}{l}\beta C 27 C 26 \mathrm{O} 41(20) ; \\
\beta O 41 C 23 C 20(17) ; \\
\beta C 28 C 27 C 26(15)\end{array}$ \\
\hline 4 & 679 & 657 & 12.71 & $\begin{array}{l}\beta \mathrm{C} 17 \mathrm{C} 15 \mathrm{C} 13(18) ; \\
\text { vB1rC12(16); } \\
\tau \mathrm{N} 36 \mathrm{C} 3 \mathrm{O} 38 \mathrm{C} 2(14) ; \\
\beta \mathrm{C} 13 \mathrm{C} 12 \mathrm{C} 10(12)\end{array}$ \\
\hline
\end{tabular}




\begin{tabular}{|c|c|c|c|c|}
\hline 5 & 710 & 686 & 7.14 & $\tau \mathrm{N} 36 \mathrm{C} 3 \mathrm{O} 38 \mathrm{C} 2(18)$ \\
\hline 6 & 754 & 729 & 29.34 & $\begin{array}{l}\tau \mathrm{O} 39 \mathrm{C} 6 \mathrm{O} 40 \mathrm{C} 19(34) ; \\
\nu \mathrm{C} 32 \mathrm{C} 7(10)\end{array}$ \\
\hline 7 & 886 & 857 & 12.84 & $\begin{array}{l}\text { vO40C20(22); } \\
\text { гH24C23O41C26(14); } \\
\text { vC23C20(10) } \\
\text { vC28C27(15); }\end{array}$ \\
\hline 8 & 911 & 881 & 6.87 & $\begin{array}{l}\text { vC28C27(15); } \\
\text { vO41C23(14); } \\
\text { гH14C13C15C17(11); } \\
\text { гH18C17C9C4(10) }\end{array}$ \\
\hline 9 & 969 & 937 & 23.41 & $\begin{array}{l}\beta \mathrm{H} 44 \mathrm{C} 43 \mathrm{C} 27(26) ; \\
\nu \mathrm{C} 28 \mathrm{C} 27(13)\end{array}$ \\
\hline 10 & 1117 & 1080 & 15.71 & $\begin{array}{l}\beta \mathrm{H} 14 \mathrm{C} 13 \mathrm{C} 15(22) ; \\
\text { } \mathrm{C} 17 \mathrm{C} 15(17) ; \\
\text { } \mathrm{C} 12 \mathrm{C} 10(12) ; \\
\text { } \mathrm{C} 13 \mathrm{C} 12(12) ; \\
\beta \mathrm{H} 18 \mathrm{C} 17 \mathrm{C} 9(10)\end{array}$ \\
\hline 11 & 1140 & 1102 & 100 & $\begin{array}{l}\text { vC6C4(19); } \\
\text { vC32C7(12) }\end{array}$ \\
\hline 12 & 1357 & 1312 & 12.54 & $\begin{array}{l}\text { гН5C4C9C10(26); } \\
\text { 乃H5C4C9(21) }\end{array}$ \\
\hline 13 & 1394 & 1348 & 45.37 & $\begin{array}{l}\text { гH21C20O40C19(20); } \\
\text { гH24C23O41C26(19); } \\
\text { гH25C23O41C26(12); } \\
\text { гH22C20O40C } 19(11)\end{array}$ \\
\hline 14 & 1420 & 1373 & 7.71 & $\begin{array}{l}v \mathrm{~N} 36 \mathrm{C} 2(22) \\
\beta \mathrm{C} 3 \mathrm{C} 2 \mathrm{O} 38(15) ; \\
\beta \mathrm{H} 35 \mathrm{C} 32 \mathrm{H} 34(10)\end{array}$ \\
\hline 15 & 1436 & 1389 & 18.46 & $\begin{array}{l}\beta \mathrm{H} 45 \mathrm{C} 43 \mathrm{H} 44(33) ; \\
\beta \mathrm{H} 31 \mathrm{C} 28 \mathrm{H} 30(18) \\
\beta \mathrm{H} 18 \mathrm{C} 17 \mathrm{C} 9(22) ;\end{array}$ \\
\hline 16 & 1453 & 1405 & 19.8 & $\begin{array}{l}\beta \mathrm{H} 14 \mathrm{C} 13 \mathrm{C} 15(15) ; \\
\beta \mathrm{H} 5 \mathrm{C} 4 \mathrm{C} 9(12) ; \\
v \mathrm{C} 12 \mathrm{C} 10(10)\end{array}$ \\
\hline 17 & 1504 & 1455 & 27.59 & $\begin{array}{l}\beta \mathrm{H} 16 \mathrm{C} 15 \mathrm{C} 17(26) ; \\
\beta \mathrm{H} 11 \mathrm{C} 10 \mathrm{C} 9(18) ; \\
v \mathrm{C} 13 \mathrm{C} 12(10) ; \\
\beta \mathrm{H} 14 \mathrm{C} 13 \mathrm{C} 15(10)\end{array}$ \\
\hline 18 & 1607 & 1554 & 44.69 & $\begin{array}{l}\nu \mathrm{C} 15 \mathrm{C} 13(30) ; \\
\nu \mathrm{C} 9 \mathrm{C} 17(18) ; \\
\beta \mathrm{C} 13 \mathrm{C} 12 \mathrm{C} 10(11) ; \\
\beta \mathrm{C} 9 \mathrm{C} 17 \mathrm{C} 15(11)\end{array}$ \\
\hline 19 & 1763 & 1705 & 55.97 & vO39C19(77) \\
\hline 20 & 1777 & 1719 & 34.45 & vO42C26(83) \\
\hline 21 & 2299 & 2223 & 17.73 & $\begin{array}{l}\vee \mathrm{N} 37 \mathrm{C} 8(88) \\
\downarrow \mathrm{C} 8 \mathrm{C} 3(12)\end{array}$ \\
\hline 22 & 3170 & 3066 & 10.46 & $\begin{array}{l}\text { vC15H16(68); } \\
\text { vC17H18(27) }\end{array}$ \\
\hline 23 & 3190 & 3085 & 2.9 & vC10H11(98) \\
\hline 24 & 3203 & 3097 & 8.42 & $\begin{array}{l}\text { vC13H14(88); } \\
\text { vC15H16(10) }\end{array}$ \\
\hline 25 & 3238 & 3131 & 6.24 & $\begin{array}{l}\nu \mathrm{C} 43 \mathrm{H} 45(59) \\
\mathrm{v} 43 \mathrm{H} 44(41)\end{array}$ \\
\hline 26 & 3573 & 3455 & 39.47 & $\begin{array}{l}v \mathrm{~N} 36 \mathrm{H} 46(50) \\
v \mathrm{~N} 36 \mathrm{H} 47(50)\end{array}$ \\
\hline 27 & 3686 & 3564 & 27.33 & $\begin{array}{l}v \mathrm{~N} 36 \mathrm{H} 46(50) \\
v \mathrm{~N} 36 \mathrm{H} 47(50)\end{array}$ \\
\hline
\end{tabular}

\section{E. Mulliken population analysis of $4 \mathbf{H}$-pyran derivative} 1

The charge distributions (total) of $4 \mathrm{H}$-pyran derivative 1 , derived from the Mulliken methodology are given in Table IV. The symbolic depiction of distribution of Mulliken charge is furnished in Fig. 6 and the equivalent plot is given in Fig. 7. A survey of mulliken plot of $4 \mathrm{H}$-pyran derivative 1 reveals that the molecule has relatively higher number of nucleophilic centres. The electrophilic behaviour is pronounced only to a limited number of atoms viz., C3 (1.05), C6 (1.28), C9 (0.62), $\mathrm{C} 17$ (0.21) and $\mathrm{C} 27$ (0.63) and their electrophilicity ranges from 0.21 (C17) to 1.28 (C6). Further, the electrophilic nature of the atoms is ascribable to the fact that they are attached to electron withdrawing neighbours such as $\mathrm{C} 2(-0.51), \mathrm{C} 7$ $(-0.55), \mathrm{C} 8(-0.74), \mathrm{C} 19(-0.55), \mathrm{C} 28(-0.60)$ and C43 (-0.37).

Table- IV: Mulliken Atomic Charges for $4 H$-pyran derivative 1

\begin{tabular}{cccc}
\hline Atom & Atomic Charge & Atom & Atomic Charge \\
\hline $1 \mathrm{Br}$ & -0.13373 & $20 \mathrm{C}$ & -0.18059 \\
$2 \mathrm{C}$ & -0.51371 & $23 \mathrm{C}$ & -0.27579 \\
$3 \mathrm{C}$ & 1.054296 & $26 \mathrm{C}$ & -0.23713 \\
$4 \mathrm{C}$ & -0.23602 & $27 \mathrm{C}$ & 0.637876 \\
$6 \mathrm{C}$ & 1.281876 & $28 \mathrm{C}$ & -0.60541 \\
$7 \mathrm{C}$ & -0.55784 & $32 \mathrm{C}$ & -0.4503 \\
$8 \mathrm{C}$ & -0.74582 & $36 \mathrm{~N}$ & -0.31659 \\
$9 \mathrm{C}$ & 0.625856 & $37 \mathrm{~N}$ & -0.20045 \\
$10 \mathrm{C}$ & -0.40154 & $38 \mathrm{O}$ & -0.07609 \\
$12 \mathrm{C}$ & -0.07612 & $39 \mathrm{O}$ & -0.1779 \\
$13 \mathrm{C}$ & -0.23523 & $40 \mathrm{O}$ & -0.00289 \\
$15 \mathrm{C}$ & -0.39832 & 410 & -0.05609 \\
$17 \mathrm{C}$ & 0.219406 & $42 \mathrm{O}$ & -0.25511 \\
$19 \mathrm{C}$ & -0.55863 & $43 \mathrm{C}$ & -0.37055 \\
\hline
\end{tabular}

The charge transfer probably occurs significantly in the following pairs as per the observation: $\mathrm{C} 3 \rightarrow \mathrm{C} 8, \mathrm{C} 6 \rightarrow \mathrm{C} 19$ and $\mathrm{C} 6 \rightarrow \mathrm{C} 7, \quad \mathrm{C} 9 \rightarrow \mathrm{C} 10, \quad \mathrm{C} 17 \rightarrow \mathrm{C} 15, \quad \mathrm{C} 27 \rightarrow \mathrm{C} 28 \quad$ and $\mathrm{C} 27 \rightarrow \mathrm{C} 43$. It is also noted that some of the atoms show neither electrophilic nor nucleophilic tendencies to an appreciable level. On inspection, the atoms $\mathrm{Br} 1, \mathrm{C} 12$, O38, O40 and 041 are found to possess less charge than the expected values.

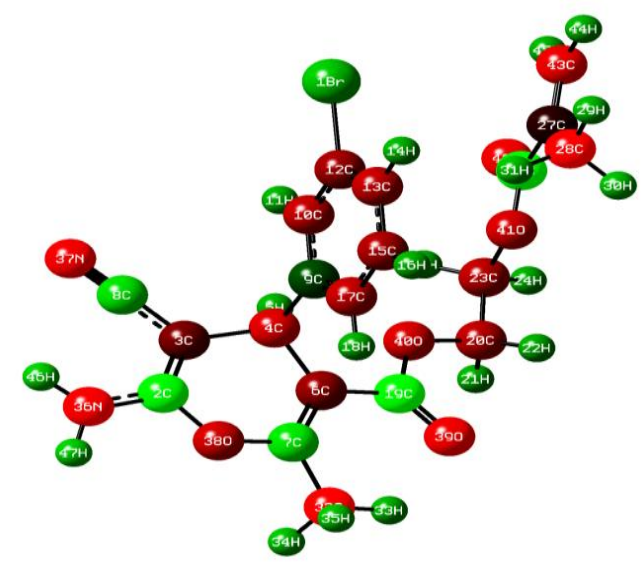

Fig. 6. Mulliken charge distribution of $4 \mathrm{H}-$ pyran derivative 1 


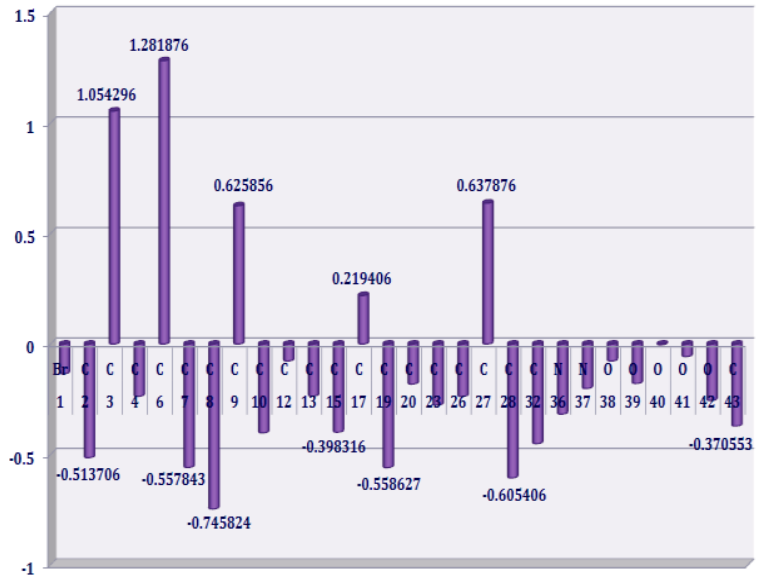

Fig. 7. Mulliken atomic charges for $4 \mathrm{H}$-pyran derivative 1

\section{F. Molecular electrostatic potential of $4 \mathrm{H}-$ pyran derivative 1}

Electrostatic Potential mapping normally provides a visual scheme to classify the comparative polarity of a compound. Fig. 8 exhibits the MEP surface plot for $4 H$-pyran derivative 1. The divergent electrostatic potential values on the surface are assigned by diverse range of colors; blue indicates most positive regions, red represents most negative regions, and green points out zero potential.



Fig.8. MEP mapping of 4H-pyran derivative 1

The classification of increasing potential is, red $<$ orange $<$ yellow < green $<$ blue. The nucleophiles tend to the positive and the electrophiles tend to the negative. The carbonyl groups $\mathrm{C} 18=\mathrm{O} 29, \mathrm{C} 26=\mathrm{O} 42$ and cyano group $\mathrm{C} 8 \equiv \mathrm{N} 37$ of title compound $\mathbf{1}$ have more electron density as the region around them appears red and they are being the possible sites for electrophilic attack. The nitrogen atom of amino group (N36) is represented by blue colour and being a possible site for nucleophilic attack.

\section{G. FMO analysis of $\mathbf{4 H}$-pyran derivative 1}

The difference in energy between HOMO and LUMO generally elucidates the charge switchover in a molecule and clarifies the chemical and biological activities of a molecule. If the difference in energy between HOMO and LUMO is found to be large, the molecule possesses more stability and hence the reactivity would be less. The energies of FMO and their difference for the $4 H$-pyran derivative $\mathbf{1}$ are tabulated in Table V. In the case of molecule 1, the electrons of HOMO are delocalized over phenyl ring only (Fig. 9), while the electrons of LUMO are delocalized over carbonyl and methylene groups

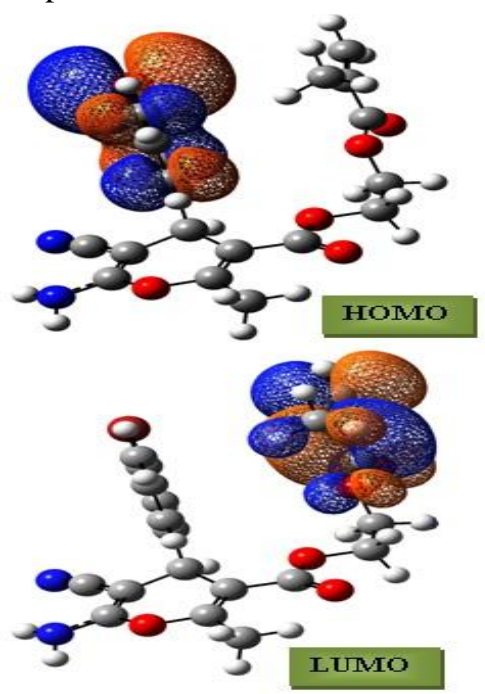

Fig. 9. HOMO-LUMO plot of 4H-pyran derivative 1

Table- V: Calculated HOMO-LUMO energies of $4 H$-pyran derivative 1

\begin{tabular}{ccc}
\hline Parameters & Energies $(\Delta \mathrm{E})$ & Band Gap (a.u) \\
\hline HOMO & 0.07074 & 0.16822 \\
LUMO & 0.23896 & \\
\hline
\end{tabular}

\section{CONCLUSION}

Single crystal of target molecule 1 has been grown by adopting slow evaporation methodology. Complete structural and vibrational properties of the same have been analysed by adopting computational and single crystal x-ray diffraction studies. The MEP visibly exposes the existence of more positive charge around the amino moiety. The FMO calculated energies reflect the occurrence of charge transfer within the molecule. XRD analysis (single crystal) of the molecule 1 supports the "flattened boat" conformation of the pyran moiety.

\section{ACKNOWLEDGMENT}

Financial assistance provided by the Indian Council of Medical Research, New Delhi (No.58/16/2013BMS) and Kalasalingam Academy of Research and Education (PDF to $\mathrm{CU}$ and $\mathrm{KG}$ ) Anand nagar, India is gratefully acknowledged.

\section{REFERENCES}

1. M. C. Pirrung, K. D. Sarma, "Multicomponent Reactions Are Accelerated in Water", J. Am. Chem. Soc, vol. 126, pp. 444-445, 2004.

2. E. Ruijter, R. V. A. Orru, "Multicomponent reactions - opportunities for the pharmaceutical industry", Drug Discovery Today: Technologies, vol. 10, pp. 15-20, 2013.

3. M. K. Ghorai, R. Talukdar, D. P. Tiwari, "An efficient synthetic route to carbocyclic enaminonitriles via Lewis acid catalysed domino-ring-opening-cyclisation (DROC) of donor-acceptor cyclopropanes with malononitrile", Chem. Commun, vol. 49, pp. 8205-8207, 2013.

4. Y. Hayashi, "Pot economy and one-pot synthesis", Chem. Sci, vol. 7 , pp. 866-880, 2016. 
5. S. Nagaraju, K. Sathish, B. Paplal, D. Kashinath, "On-water" catalyst-free, one pot synthesis of quaternary centered and spiro-tetrahydrothiophene-barbiturate hybrids", Tetrahedron Lett, vol. 58, pp. 2865-2871, 2017

6. D. Srikrishna, P. K. Dubey, "PEG-600 mediated one-pot reaction of 3-acetyl-2H-chromene-2-one with heterylthiols and phenylthioureas using tetrabutylammonium tribromide as an efficient green reagent", New J. Chem, vol. 41, pp. 5168-5175, 2017.

7. G. Dupeyre, P.Lemoine, N. Ainseba, S. Michel, X. Cachet, “A one-pot synthesis of 7-phenylindolo[3,2-a] carbazoles from indoles and $\beta$-nitrostyrenes, via an unprecedented reaction sequence", Org. Biomol. Chem, vol. 9, pp. 7780-7790, 2011

8. S. Huang, Y. Pan, Y. Zhu, A. Wu, “ A Novel Three-Component One-Pot Reaction Involving Alkynes, Urea or Thiourea and Aldehydes", Org. Lett, vol. 7, pp. 3797-3799, 2005.

9. C. Ramalingan, S. J. Park, I. S. Lee, Y. W. Kwak, "A piperidinium triflate catalyzed Biginelli reaction”, Tetrahedron, vol. 66, pp. 2987-2994, 2010.

10. C. Ramalingan, Y. W. Kwak, "Tetrachlorosilane catalyzed multicomponent one-step fusion of biopertinent pyrimidine heterocycles", Tetrahedron, vol. 64, pp. 5023-5031, 2008.

11. S. W. Youn, E. M. Lee, "Metal-Free One-Pot Synthesis of N,N'-Diarylamidines and N-Arylbenzimidazols from Arenediazonium salts, Nitriles, and Free Anilines", Org. Lett, vol. 18, pp. 5728-5731, 2016.

12. M. Zangouei, A. A. Esmaeili, J. T. Mague, "One-pot three component isocyanide-based reaction: Synthesis of novel tetracyclic fused furo[2',3':4,5] pyrimido[2,1-b][1,3]benzothiazole", Tetrahedron, vol. 73, pp. 2894-2900, 2017

13. J. L. Wang, D. Liu, Z. J. Zhang, S. Shan, X. Han, S. M. Srinivasula, C. M. Croce, E. S. Alnemri, Z. Huang, "Structure-based discovery of an organic compound that binds Bcl-2 protein and induces apoptosis of tumor cells”, Proc. Natl. Acad. Sci., USA vol. 97, pp 7124-29, 2000.

14. Y. Peng, G. Song, "Amino-functionalized ionic liquid as catalytically active solvent for assisted synthesis of $4 \mathrm{H}$-pyrans", Catal. Commun, vol. 8, pp. 111-114, 2007.

15. J. Y. C. Wu, W. F. Fong, J. X. Zhang, C. H. Leung, H. L. Kwong, M. S Yang, D. Li, H. Y. Cheung, "Reversal of multidrug resistance in cancer cells by pyranocoumarins isolated form Radix Peucedani”, Eur. J. Pharmacol, vol. 473, pp. 9-17, 2003.

16. T. Raj, R. K. Bhatia, A. Kapur, M. Sharma, A. K. Saxena, M. P. S. Ishar, "Cytotoxic activity of 3-(5-phenyl-3H-[1,2,4]dithiazol-3-yl)chromen-4-ones and 4-oxo-4H-chromene-3-carbothioic acid N-phenylamides", Eur. $J$. Med. Chem, vol. 45, pp. 790-794, 2010.

17. M. T. Flavin, J. D. Rizzo, A. Khilevich, A. Kucherenko, A. K. Sheinkman, V. Vilaychack, L. Lin, W. Chen, E. M. Greenwood, T. Pengsuparp, J. M. Pezzuto, S. H. Hughes, T. M. Flavin, M. Cibulski, W. A. Boulanger, R. L. Shone, Z. Q. Xu, "Synthesis, chromatographic resolution and anti-human immunodeficiency virus activity of (+/-) calanolide A and its enantiomers", J. Med. Chem, vol. 39, pp 1303-1313, 1996.

18. D. O. Moon, K. C. Kim, C. Y. Jin, M. H Han, C. Park, K. J. Lee, Y. M. Park, Y. H. Choi, G. Y. Kim, "Inhibitory effects of eicosapentaenoic acid on lipopolysaccharide-induced activation in BV2 microglia", Int Immunopharmacol, vol. 7, pp. 222-229, 2007.

19. E. Perez-Sacau, A. Estevez-Braun, A. G. Ravelo, D. G. Yapu, A. G. Turba, "Antiplasmodial Activity of Naphthoquinones Related to Lapachol and $\beta$-Lapachone", Chem. Biodiversity, vol. 2, pp. 264-274 2005 .

20. L. R. Morgan, B. S. Jursic, C. L. Hooper, D. M. Neumann, K. Thangaraj, B. Leblance, "Anticancer activity for 4,4'-Dihydroxybenzophenone-2,4-dinitrophenylhydrazone (A-007) analogues and Their abilities to interact with lymphoendothelial cell surface markers", Bioorg. Med. Chem. Lett, vol. 12, pp. 3407-3411, 2002.

21. T. Akbarzadeh, A. Rafinejad, J. M. Mollaghasem, M. Safari, A. F. Tafti, M. Pordeli, S. K. Ardestani, A. Shafiee, A. Foroumadi, "2-Amino-3-cyano-4-(5-arylisoxazol-3-yl)-4H-chromenes: Synthesis and In Vitro Cytotoxic Activity", Arch. Pharm. Chem. Life Sci, vol. 345, pp. 386-392, 2012.

22. M. Mahmoodi, A. Aliabadi, S. Emami, M. Safavi, S. Rajabalian, M. Mohagheghi, A. Khoshzaban, A. Samzadeh-Kermani, N. Lamei, A Shafiee, A. Foroumadi, "Synthesis and in-vitro Cytotoxicity of Poly-functionalized 4-(2-Arylthiazol-4-yl)-4H-chromenes", Arch. Pharm. Chem. Life Sci, vol. 343, pp. 411-416, 2010.

23. S. Abdolmohammadi, S. Balalaie, "Novel and efficient catalysts for the one-pot synthesis of 3,4-dihydropyrano[c]chromene derivatives in aqueous media", Tetrahedron Lett, vol. 48, pp. 3299-3303, 2007.

24. K. Gong, H. L. Wang, J. Luo, Z. L. Liu, "One-pot synthesis of polyfunctionalized pyrans catalyzed by basic ionic liquid in aqueous media", J. Heterocycl. Chem, vol. 46, pp. 1145-1150, 2009.

25. Y. Essamlali, O. Amadine, H. Maati, K. Abdelouahdi, A. Fihri, M. Zahouily, R. S. Varma, A. Solhy, "Highly efficient one-pot three-component synthesis of naphthopyran derivatives in water catalyzed by phosphates", ACS Sustainable Chem. Eng, vol. 1, pp. 1154-1159, 2013

26. G. Sheldrick, "A short history of SHELX", Acta Crystallogr. Sect. A, vol. 64, pp. 112-122, 2008

27. L. J. Farrugia, "WinGX suite for small-molecule single-crystal crystallography”, J. Appl. Crystallogr, vol. 32, pp. 837-838, 1999.

28. L. J. Farrugia, J. Appl. Crystallogr, vol. 30, pp. 565-566, 1997.

29. T. Vreven, K. N. Kudin, J. C. Burant, J. M. Millam, S. S. Iyengar, J. Tomasi, V. Barone, B. Mennucci, M. Cossi, G. Scalmani, N. Rega, G. A. Petersson, H. Nakatsuji, M. Hada, M. Ehara, K. Toyota, R. Fukuda J. Hasegawa, M. Ishida, T. Nakajima, Y. Honda, O. Kitao, H. Nakai, M. Klene, X. Li, J. E. Knox, H. P. Hratchian, J. B. Cross, V. Bakken, C. Adamo, J.Jaramillo, R. Gomperts, R. E. Stratmann, O. Yazyev, A. J. Austin, R. Cammi, C. Pomelli, J. W. Ochterski, P. Y. Ayala, K Morokuma, G. A. Voth, P. Salvador, J.J. Dannenberg, V. G Zakrzewski, S. Dapprich, A. D. Daniels, M. C. Strain, O. Farkas, D. K Malick, A. D. Rabuck, K. Raghavachari, J. B. Foresman, J. V. Ortiz, Q Cui, A. G. Baboul, S. Clifford, J. Cioslowski, B. B. Stefanov, G. Liu, A. Liashenko, P. Piskorz, I. Komaromi, R. L. Martin, D. J. Fox, T. Keith, M. A. Al-Laham, C. Y. Peng, A. Nanayakkara, M Challacombe, P. M. W. Gill, B. Johnson, W. Chen, M. W. Wong, C. Gonzalez, J. A. Pople, Gaussian 09, Revision C.02; Gaussian, Inc., Wallingford CT 2004

30. M. H. Jomroz, Vibrational Energy Distribution Analysis, VEDA4, Warsaw, 2004

31. G. Socrates, Infrared and Raman Characteristic Group Wave Numbers - Tables and Charts, third ed., John Wiley and sons, New York, (2001).

32. V. Arjunan, S. Thirunarayanan, S. Mohan, "Energy profile, spectroscopic (FT-IR, FT-Raman and FT-NMR) and DFT studies of 4-bromoisophthalic acid", J. Mol. Struct, vol. 1157, pp. 132-148, 2018 .

\section{AUTHORS PROFILE}



Dr. Chandran Udhaya Kumar Graduated from Thyagaraja College, Madurai (2009) and pursued doctoral research in Organic Chemistry at Annamalai University (2014). He then served as postdoctoral fellow at Kalasalingam Academy of Research and Education, Krishnankoil, India (2015-2018). He published 24 research articles in peer-reviewed journals. His areas of research are Organic Synthesis, X-ray crystallography and Computational Chemistry.

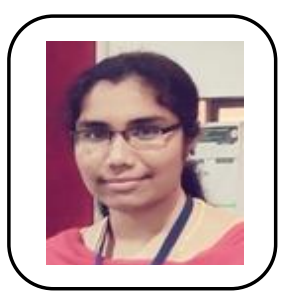

chemistry.

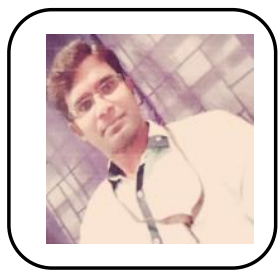

Shunmugam Iniyaval obtained her Bachelor of Science degree in Chemistry from Sri Parasakthi College for Women, Courtrallam in 2013. She earned her Master's degree in Chemistry in 2015 from Sri Paramakalyani College, Alwarkuruchi. She is currently a $\mathrm{PhD}$ student at Kalasalingam Academy of Research and Education, Krishnankoil. She has been working in the area of heterocyclic synthesis and medicinal

Dr. Kannan Gokula Krishnan Graduated from Sacred Heart College, Thiruppathur (2009) and completed his doctoral degree in Organic Chemistry at Annamalai University (2015). He then prosecuted his postdoctoral research at Kalasalingam Academy of Research and

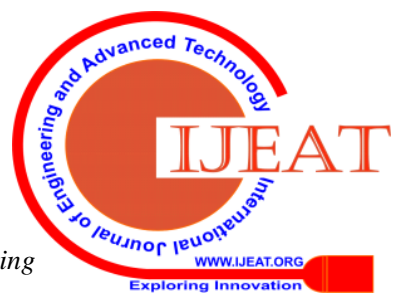


Education, Krishnankoil, India (2015-2018). He published 10 research articles in peer-reviewed journals. His areas of research are Organic Synthesis, development of biopertinent molecules and Computational Chemistry.

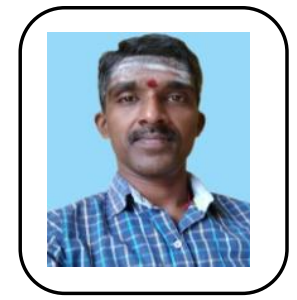

Dr. Muthiah Pillai Velayutham Pillai had his graduation from Christian College, Nagercoil (1997) and earned his doctoral degree from Annamalai University (2014). Presently, he is serving as Assistant Professor of Chemistry at Kalasalingam Academy of Research and Education, Krishnankoil, India. His areas of research are Organic Synthesis, Crystallography ad research articles in peer-reviewed journals.

Computational Chemistry. He published 14

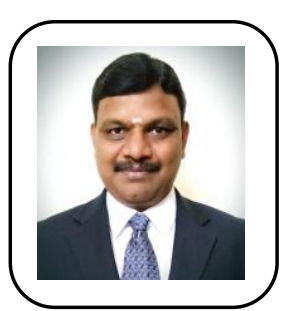

Dr. Chennan Ramalingan is serving as Professor of Chemistry at KARE. He received his $\mathrm{PhD}$ in Organic Chemistry from Annamalai University (2002). After he served as Research Professor at Kyungpook National University, South Korea followed by Assistant Professor at Osaka University, Japan (8 years), he joined at Kalasalingam Academy of Research and Education, Krishnankoil (2011). His research interests include organic synthesis, medicinal chemistry and material chemistry. He published more than 70 International research articles. 